[総説 ]

\title{
照射食品の誘導放射能の評価
}

\author{
古田雅一 \\ 大阪府立大学大学院（干 599-8570 大阪府堺市学園町 1-2）
}

\section{Evaluation of induced radiaoactivity in irradiated foods}

\author{
Masakazu FURUTA \\ Osaka, Prefecture .University, 1-2 Gakuen-cho, Sakai, Osaka 599-8570 Japan
}

本稿は, 2006 年 2 月 17 日に開催された第 3 回原 子力委員会食品照射専門部会の議事録より, 古田雅 一氏の了解を得て, 当日古田氏が述べた意見を日本 食品照射研究協議会事務局がまとめたものである。

はじめに

放射線照射食品の安全性に関しては, 放射性照射 で毒性のある分解生成物が生じないかということが 一番大きな問題と思われます。食品も有機化合物の 集合体であり, 放射線が当たると放射線化学反応が 起こり，それによって独特の反応生成物ができる可 能性があるので, それについての毒性が, 微生物の 細胞, 動物の細胞, あるいは動物そのものを使った 安全性試験で評価されるのです。しかし, 一般消費 者からは，放射線照射されることで食品が放射能を 帯びないか, という素朴な疑問がよく出てくるので す。私も大阪市内で毎年夏休みに開催している「み んなの暮らしと放射線展」という展示会で, 芽止め されたジャガイモを前にして, 来場者の方から「放 射線が当たっているの?」「放射能が出ているのと 違う？」といったような質問をよく受けます。この ようなことがきっかけで，放射線を当てたときに本 当に放射能が検出されるのか, もう一度しっかり確 認しておいた方が良いと思い, この研究を始めまし た。

\section{放射線照射で食品が放射能を帯びる場合}

先ず，放射線照射で食品が放射能を帯びる場合が
あるか否かについて，文献を調べたところ，かなり 古くから検討されていることがわかりました。1950 年代〜 60 年代, 特にアメリカ合衆国陸軍の研究所 を中心に，非常に詳細な検討が行われていました。 しかし，その検討は，いわゆる物理学的な放射線物 理を基本とした理論的評価による検討でした。専門 家の方には, 通常, 食品照射に使用される放射線で あるコバルトー60 あるいはセシウム-137 から出てく るガンマ線, $10 \mathrm{MeV}$ (メガエレクトロンボルト；エ ネルギーの単位) までの電子線, $5 \mathrm{MeV}$ の X線と いった程度の放射線であ机ば問題ないことは常識に なっており，1981年の FAO (国連食料宸業機関), IAEA (国際原子力機関)，WHO の合同専門家委員 会が出した食品照射の安全宣言の中でも謳われてい ます。しかしながら，私自身も理科系ですが，生物 系, 農学系ですので, この辺りの理論的評価を一目 見て理解するのはなかなか難しく，ましてや一般消 費者の方にはかなり分かりづらいのではないかと思 われます。核反応の起こりやすさの評価を明らかに し, 実際に放射線を照射された食品の放射能測定を 行う必要があるのでは，思いました。

\section{核反応の起こりやすさの評価}

先ず，核反応の起こりやすさの評価ですが，先述 の理論的な評価の流れにも沿いながら説明します。

食品は有機化合物の集合体ですが，さらに細かく 見ていきますと, 食品の最小構成単位は原子であ り, 有機物分子を構成する炭素, 水素, 窒素, 酸素 
といった元素が圧倒的に多いわけです。そこで，他 の元素についてさらに詳しい元素分析を行ってみま した (表 1)。

食品は黒コショウと白コショウですが，いろいろ な元素が並んでいます。ナトリウムから始まり，ア ルミニウム, 硫黄, 塩素, カリウム, カルシウムと, だんだん重くなっていきます。ウラン，トリウム， 水銀などのように非常に重い元素も微量ながら含ま れていることがわかります。これは, 中性子放射化 分析法という分析法に基づいて測定しました。

元素の構造（図1）についてですが，原子は原子 核が核になり，この中に中性子と陽子が主に含まれ ています。その周りを電子が回り, 最も軽い元素で ある水素の場合，原子核に陽子が 1 個あり，その周 りに電子が 1 個回っています。重い元素の炭素です と, 原子核の陽子の数は 6 つというように, 元素が 重くなっていくにつれ，原子核の陽子と中性子の数 はだんだん増えることが知られています。

そこで，このような元素の集合体に放射線が当 たった場合, 元素が何か反応して放射線を出す, 放 射性同位元素に変わる, ということが起こり得るの かどうかを次に検討しました。

放射線物理の世界では，既にいろいろな研究がな され，そうした反応が起こることが分かっており，

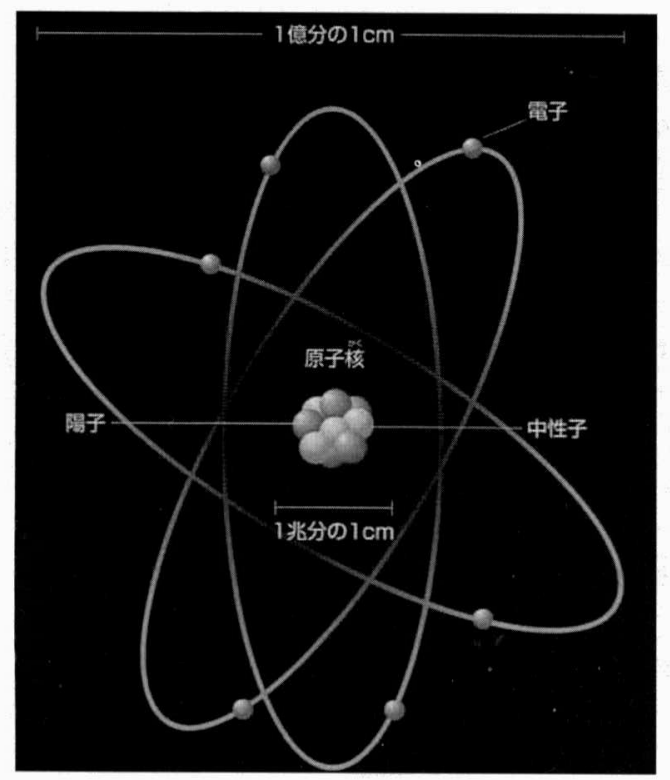

図 1 元素の構造
それを核反応（図2）と呼んでいます。

表 1 Elenental composition of pepper measured with neutron activation analysis

\begin{tabular}{|c|c|c|c|c|c|}
\hline \multirow{3}{*}{$\begin{array}{l}\text { Elenent } \\
\mathrm{Na}\end{array}$} & \multicolumn{5}{|c|}{ Content (ppm) (error, \%) } \\
\hline & \multicolumn{3}{|c|}{ Black pepper } & \multicolumn{2}{|c|}{ White pepper } \\
\hline & & $7 \times 10$ & $(4)$ & $1.4 \times 10$ & (10) \\
\hline A1 & & $4 \times 10$ & (13) & $5.8 \times 10$ & ( 8 ) \\
\hline S & $<8.0$ & $0 \times 10^{3}$ & & $<2.0 \times 10$ & \\
\hline $\mathrm{C} 1$ & & $6 \times 10^{3}$ & $(5)$ & $3.6 \times 10$ & (17) \\
\hline $\mathrm{K}$ & & $2 \times 10^{4}$ & ( 3 ) & $5.9 \times 10^{2}$ & (10) \\
\hline $\mathrm{Ca}$ & & $4 \times 10^{3}$ & ( 7$)$ & $1.3 \times 10^{3}$ & ( 7$)$ \\
\hline $\mathrm{Sc}$ & & $7 \times 10^{-2}$ & $(4)$ & $8.2 \times 10^{-3}$ & ( 7 ) \\
\hline $\mathrm{Ti}$ & $<3.0$ & $0 \times 10$ & & $<1.0 \times 10$ & \\
\hline V & 2 & $\times 10^{-3}$ & $(40)$ & $1 \times 10^{-1}$ & $(40)$ \\
\hline $\mathrm{Cr}$ & & $4 \times 10^{-1}$ & $(25)$ & $9.0 \times 10^{-1}$ & (11) \\
\hline $\mathrm{Mn}$ & & $0 \times 10$ & $(23)$ & $4.0 \times 10$ & (21) \\
\hline $\mathrm{Fe}$ & & $1 \times 10$ & ( 7 ) & $6.7 \times 10$ & ( 6$)$ \\
\hline Co & & $2 \times 10^{-2}$ & ( 8$)$ & $3.2 \times 10^{-2}$ & (11) \\
\hline $\mathrm{Ni}$ & 1 & & $(32)$ & $4 \times 10^{-1}$ & $(40)$ \\
\hline $\mathrm{Cu}$ & $<1.0$ & $0 \times 10$ & & 8 & (40) \\
\hline $\mathrm{Zn}$ & & $2 \times 10$ & $(5)$ & $1.0 \times 10$ & (4) \\
\hline As & & $\times 10^{-2}$ & & $<3.0 \times 10^{-2}$ & \\
\hline $\mathrm{Se}$ & $<5$ & $\times 10^{-2}$ & & $<5.0 \times 10^{-2}$ & \\
\hline $\mathrm{Br}$ & & $3 \times 10$ & ( 3$)$ & $8.9 \times 10^{-1}$ & ( 3 ) \\
\hline $\mathrm{Rb}$ & & $5 \times 10$ & ( 3 ) & $9.3 \times 10^{-1}$ & (12) \\
\hline Mo & & $0 \times 10^{-1}$ & (29) & $3.4 \times 10^{-1}$ & (14) \\
\hline $\mathrm{Ag}$ & $<3.0$ & $0 \times 10^{-2}$ & & $<3.0 \times 10^{-2}$ & \\
\hline $\mathrm{Cd}$ & $<2.0$ & $0 \times 10^{-2}$ & & $<1.0 \times 10^{-1}$ & \\
\hline Sn & $<3$ & & & $<1$ & \\
\hline $\mathrm{Sb}$ & 6 & $\times 10^{-2}$ & $(40)$ & $1.1 \times 10^{-3}$ & (21) \\
\hline I & $<6$ & $\times 10^{-1}$ & & $<7 \times 10^{-1}$ & \\
\hline Cs & & $4 \times 10^{-2}$ & $(8)$ & $1 \times 10^{-2}$ & (40) \\
\hline $\mathrm{Ba}$ & & $1 \times 10$ & (11) & $1.4 \times 10$ & (14) \\
\hline $\mathrm{La}$ & & $0 \times 10^{-2}$ & (15) & $3.2 \times 10^{-2}$ & (19) \\
\hline $\mathrm{Ce}$ & & $\times 10^{-2}$ & (40) & $<5 \times 10^{-2}$ & \\
\hline Sn & & $5 \times 10^{-3}$ & ( 8 ) & $3.4 \times 10^{-3}$ & (19) \\
\hline $\mathrm{Eu}$ & & $\times 10^{-3}$ & & $6 \times 10^{-4}$ & (40) \\
\hline $\mathrm{Yb}$ & $<1$ & $\times 10^{-2}$ & & $<1 \times 10^{-2}$ & \\
\hline $\mathrm{Lu}$ & $<3$ & $\times 10^{-3}$ & & $<2 \times 10^{-3}$ & \\
\hline $\mathrm{Hf}$ & $<1$ & $\times 10^{-2}$ & & $<9 \times 10^{-3}$ & \\
\hline Ta & 3 & $\times 10^{-3}$ & $(40)$ & $2 \times 10^{-3}$ & (40) \\
\hline W & $<6$ & $\times 10^{-2}$ & & $<3 \times 10^{-2}$ & \\
\hline $\mathrm{Hg}$ & 2 & $\times 10^{-2}$ & $(40)$ & $<2 \times 10^{-2}$ & \\
\hline Th & & $4 \times 10^{-2}$ & (9) & $2 \times 10^{-2}$ & (40) \\
\hline $\mathrm{U}$ & $<2$ & $\times 10^{-2}$ & & $<1 \times 10^{-2}$ & \\
\hline Total & & $9 \times 10^{4}$ & & $2.1 \times 10^{3}$ & \\
\hline
\end{tabular}




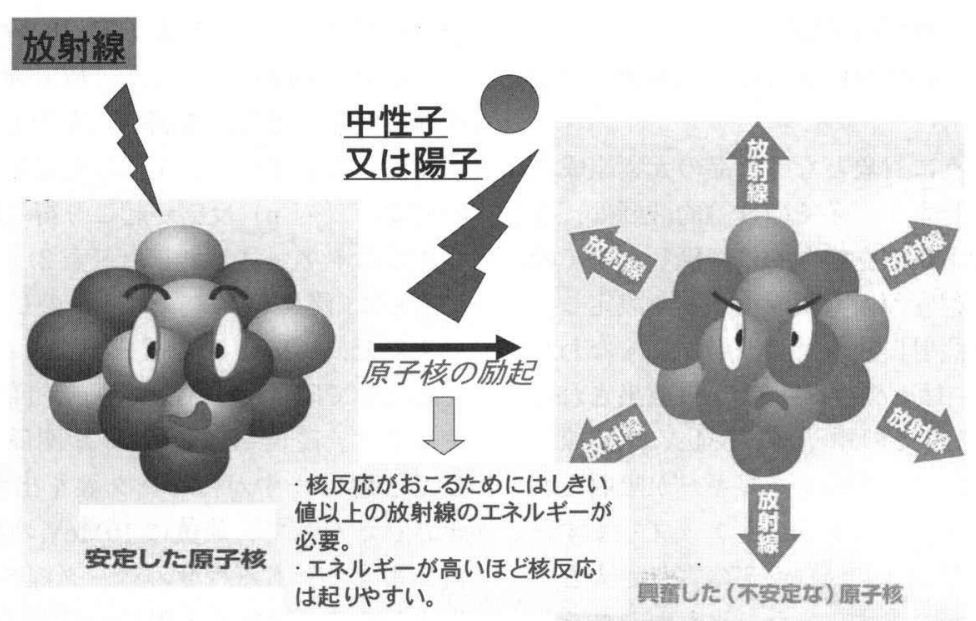

$10 \mathrm{MeV}$ 以下の放射線で問題になるのは主しして $(r, n)$ 反応！

図 2 核反応とは

核反応とは，放射線が当たり，原子の中の原子核 に放射線のエネルギーが吸収され，今まで安定に存 在している原子核の中に要らないエネルギーが入っ て原子核が励起されるというもので, 例えば, 原子 核の構成成分である中性子や陽子が邪魔になって飛 び出してしまう, といった反応です。その結果, 放 射線を出すような, 興奮した, あるいは不安定な原 子核に変わることが起こり得ます。

(注) 元素の中には，安定な元素と放射線を出す放射性 同位元素の 2 種類があります。空中にある炭素も， 大部分を占める炭素-12 は放射線を出しませんが, 大気中には炭素-14 が 0.00014\%程度あり,これは 放射性同位元素であり放射線（ベータ線）を出 し, 安定な絰素-14に変わり (壊変) します。力 リウム -40 は天然に存在するカリウム (大部分はカ リウム -39$)$ の $0.012 \%$ を占め, 大部分 $(89 \%)$ は ベータ線を出して安定なカルシウム 40 に変わり ます。一方残り $11 \%$ 「電子捕獲」によりアルゴ ン -40 に変わり, ガンマ線を出しで安定化します。 カリウムは体内にもたくさんあり, ヒトの骨を全 部集めて測りますと, 通常の検出器で検出上限を 超えるくらいのカリウム -40 由来のカウントが出 てきます。

では，放射線が当たれば必ず反応が起こり，どん どん放射能を帯びてしまうのかというと，そういう ことはありません。核反応が生じるためにはいくつ かクリアしなければならない要件があります。その $1 つ か ゙$ 放射線のエネルギーです。放射線のエネル
ギーが低い場合は核反応は起こらず, 核反応が起こ るためにはあるエネルギー以上，すなわちしきい值 以上のエネルギーが必要です。

また, しきい值以上のエネルギーの放射線が当 たってもすぐに核反応が生じるわけではありませ ん。エネルギーがしきい值に近いうちは核反応は起 こりにくく, エネルギーが高いほど核反応は起こり やすいと言われており，エネルギーが高くなれば高 くなるほど多種多様な核反応が起こり得ます。食品 照射で使われる放射線は, 一般的には $10 \mathrm{MeV}$ 以下 の放射線であり, 特にガンマ線と電子線が使われて いますが, このレベルの放射線で問題になってくる のは主として $(\gamma, \mathrm{n})$ 反応であることが, 物理学的 な検討でわかっています。ガンマ線の場合, 中性子 が放り出されて原子核の状態が変わるといった反応 が, 電子線の場合は, 電子線が当たり制動放射とい う現象が起こってガンマ線に変換され, そのガンマ 線が原子核に吸い込まれるといった反応があり，そ うした場合には $(\gamma, \mathrm{n})$ 反応が起こり得ます。

このような基礎的な情報をもとに，これまでいろ いろな研究者により誘導放射能の理論的評価がなさ れてきました。一番最近のものとしては，2002 年 4 月, IAEAが出した TECDOCという文書で, 非常に 詳しい理論的な検討結果が出ており, 現在のとこ ろ, これが, いわゆる誘導放射能の安全性に関する 決めのデータになっています。 


\section{誘導放射能の理論的評価の手順}

次に, 誘導放射能の理論的評価の手順を簡単に説 明します。

先ず, 先述のように対象となる食品の元素組成を 測定して明らかにします。多くの理論的評価は，さ まざまな食品の元素組成を総合的に評価し，全ての 食品に当てはまる程度の元素組成モデルを設定し， それに対して食品照射に使われる放射線，すなわち コバルト-60 あるいはセシウム -137 から放出される ガンマ線， $10 \mathrm{MeV}$ までの電子線， $5 \mathrm{MeV}$ の X 線と いった放射線について，そのエネルギーが吸収され た場合に起こり得る核反応をリストアップします。 その結果，ほとんどは（ $\gamma, \mathrm{n})$ 反応の寄与が大きい ことが理論的にわかります。また，それがそれぞれ の元素組成に属する特定の元素とどの程度反応する のかも理論的にわかりますので，核反応の結果生じ る可能性のある放射性同位元素量が計算上，推定で きます。つまり, どの程度の放射能が生じるのかが 机上の計算で出てくるのです。

その際に，考虑すべき要因がいくつかあります が，その一つが放射線のエネルギーレベルで，しき い值以上かどうか，ということです。エネルギーが 低いと，ある核反応は全く起こりません。また，放 射線の量についても，核反応をたくさん起こすなら ば放射線をたくさん当てればいいということにな り，対象となる元素の量も多い方がよいということ になります。また食品を透過する放射線がどの方向 にどの程度散乱し，その方向に核反応の標的となる 元素がどの程度の密度で存在するか, という要因も 考えなければなりません。さらに，同じ放射線量， 同じ元素量であっても核反応が起こるか起こらない かというような程度，これを核反応断面積と呼んで いますが，いわゆる核反応が起こる可能性といった 要因もはいってきます。こうした要因を全て考虑し て計算する必要があります。

計算の結果，現在，食品照射に用いられる放射線 のレベルである $60 \mathrm{kGy}$ を当てると，ほとんどの食品 で無菌化でき, この程度の照射で生じる誘導放射能 は事実上ゼロであると結論づけられます。

したがって，専門家の中では「もうこれで OK」 という話になるわけですが，専門外の私達には，こ れだけでは安心できないところもあるのです。

\section{放射線照射コショウによる実際的評価}

そこで，実際にコショウに放射線を当て，どの程 度の放射能が出るかを調べ, 安全であることを確認 することにしました。先述の元素組成に従って，ど の程度の $(\gamma, \mathrm{n})$ 反応が起こり得るのかを文献で調 ベ，リストアップしました（表 2)。

例えば，硫黄では，エネルギーのしきい值が $9.9 \mathrm{MeV}$ ですので, $10 \mathrm{MeV}$ の電子線が当たった場合, $(\gamma, \mathrm{n})$ 反応として硫黄-36から中性子が 1 個出て硫黄-35が 生じます。硫黄-35は, バイオ関係の方はよくご存 じだと思いますが，ベータ線を出す放射性核種で す。したがって，硫黄に $10 \mathrm{MeV}$ の放射線を次々に 当てますと, ある程度のべー夕線を出す硫黄-35が 生まれることは理論上明らかです。核反応断面䅡を 評価しますと, 確率としては非常に少ないこともわ かりますが，しきい值は全て $10 \mathrm{MeV}$ 以下の数字で すので, 食品照射の最高エネルギーである $10 \mathrm{MeV}$ の電子線を当てると, 放射性核種が出てくる可能性 があります。

では，それがどの程度のレベルであり，普通の放 射能測定ではどれ位検出されるのでしょう。

図 3 では横軸が放射線のエネルギーを表し，この 核反応がヨウ素-127 からヨウ素-126 という放射性 核種が生じる $(\gamma, \mathrm{n})$ 反応であることを示してい ます。縦軸は「Cross Section」，日本語に訳すと「核 反応断面積」ですが, 核反応がどの程度起こりやす いかという指標です。約 $7 \mathrm{MeV}$ がしきい值であり, エネルギーが高くなっていくと，例えば $10 \mathrm{MeV} の$ ところでは, ほんの少しの反応しか起こっていませ んが，エネルギーがさらに高くなると，急速にこの “反応の起こりやすさ”，すなわち「核反応断面積」

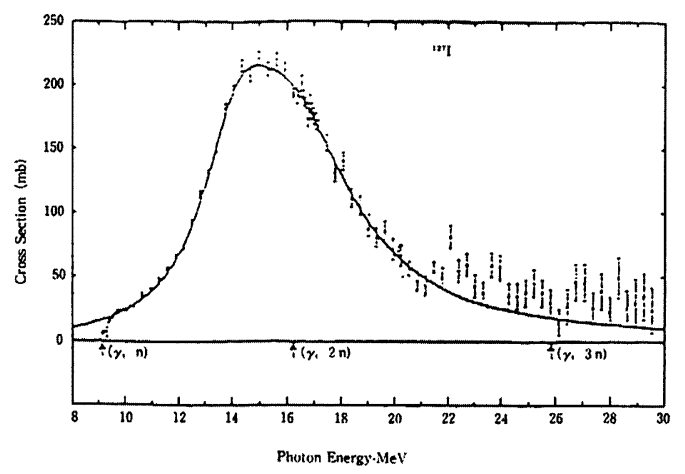

図 3 核反応 ${ }^{127} \mathrm{I}(\gamma, \mathrm{n}){ }^{126} \mathrm{I}$ の生じ易さ 
表 2 放射線照射コショウによる実際的評価

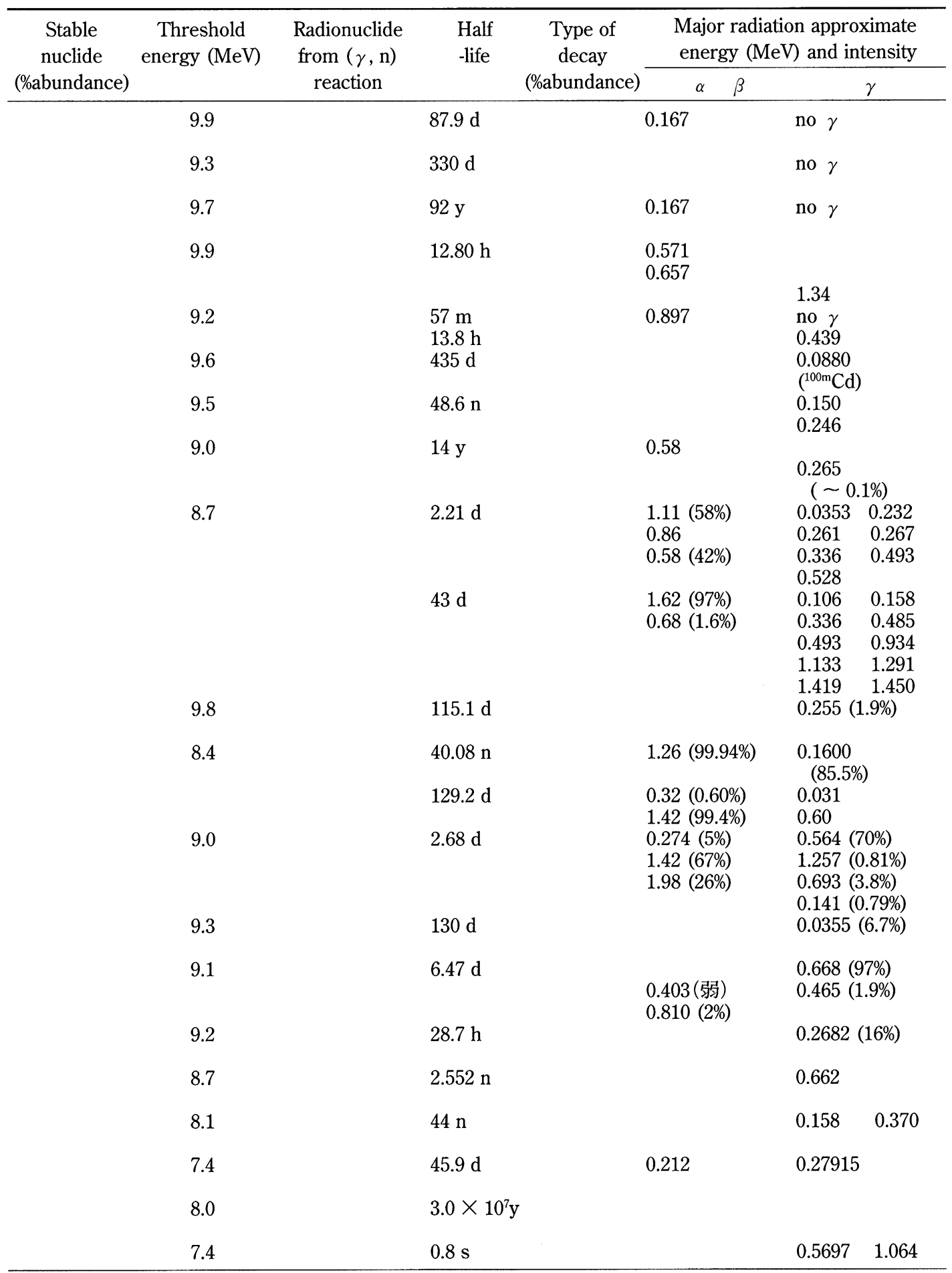


が大きくなり，実際に理想的な条件では測定するこ ともできます。

ところが，食品照射で認められている放射線エネ ルギーは $10 \mathrm{MeV}$ までであり，それより上の反応が 起こるような放射線は認められていませんので, 食 品照射で考虑するところでは反応は少ししか起こら ないということになります。この核種で実際にどの 程度の放射能が出るかを理論的に計算しますと，誘 導放射能は検出されないという結論になります。そ こで，実証試験として，次のような放射能測定を行 いました。

\section{実際の放射能測定}

・実験材料黒コショウ，白コショウ種子 （マレーシア，サラワク産）

- 放射線照射

$10 \mathrm{MeV}$ ライナック電子線, $100 \mathrm{kGy}$

- 放射能測定

$\gamma$ 線： $20 \mathrm{~cm}$ 厚みの鉄室内でリチウムドリフト ゲルマニウム検出器, 波高分析 $\beta$ 線：2 $\pi$ ガスフローカウンター

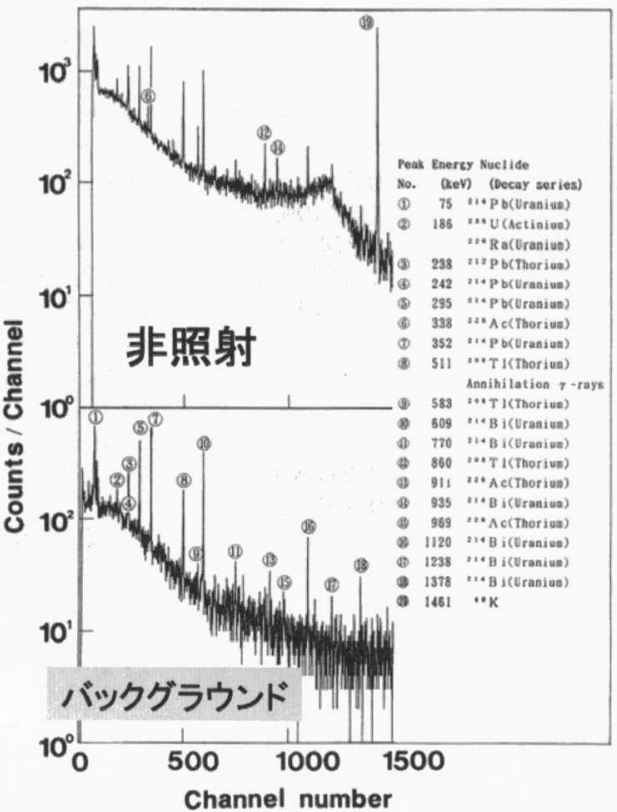

（注）通常,食品照射に用いられる放射線のうち, $10 \mathrm{MeV}$ の電子線を選んだのは，エネルギーが一番高かっ たからです。放射能を生じる核反応は，エネル ギーが高い方が起こりやすいことはわかっていま すので, 現在, 食品照射で認められている最高の エネルギーとなる電子線で, しかも放射線の量も 国際機関で推奨される $10 \mathrm{kGy}$ の 10 倍量という極 端な量を選んだわけです。

なお，香辛料の場合は $10 \mathrm{kGy}$ ですが，例えば， 宇宙食や特殊な病人食には $50 \mathrm{kGy}$ が使われる場合 もあります。が, $100 \mathrm{kGy}$ で実験をしているので,問 題ないと思います。

黒コショウと白コショウ種子に, 食品照射で用い る最高エネルギーである $10 \mathrm{MeV}$ の電子線を $100 \mathrm{kGy}$ という膨大な量を当ててみました。通常, 香辛料に 照射して殺菌する場合は, $10 \mathrm{kGy}$ 程度当てれば食品 衛生上, 問題ないレべルまで殺菌が可能なのです が，その 10 倍量という極端な量を設定しました。 放射能測定は, 現在のところ最も感度のよい放射能 測定装置を用い，ガンマ線とベータ線の測定を行い ました。「鉄室内で」とありますが，これは鉄の壁 で囲い，外から入ってくる自然放射線をできるだけ 遮断するという措置です。私達の居住空間には自然 放射線が飛び交っており，非常に高感度な測定器を

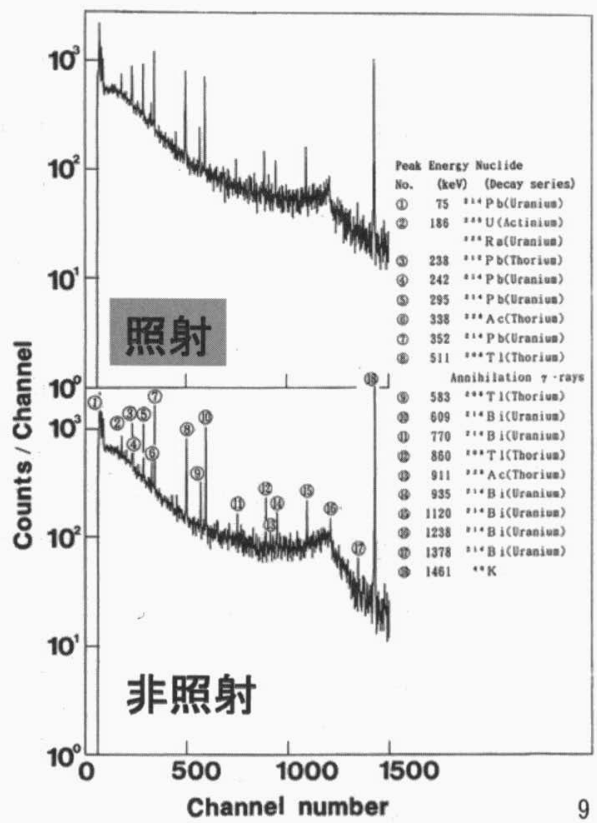

b

図 4 黒コショウの $\gamma$ 線測定結果 
用いると，この自然放射線も十分測定されてしまう からです。この措置により, 食品そのものから出て くる放射線がより感度よく測れることになります。

図 $4 \mathrm{a}, \mathrm{b}$ は, 黒コショウの測定の解析結果です。 図4aが，何もいれないときと照射していないコ ショウを同じレベルで放射能測定し比較したもので す。何もいれないとき，すなわちバックグラウンド でもこの程度のレベルの自然放射線が観測されま す。ピークがいろいろ出ていますが, 全て土や岩石 の中から生じる，専門的に言いますとウラン系列あ るいはトリウム系列と呼ばれる自然放射線であるこ とが同定できました。照射していない黒コショウで は，こうした自然放射線によるピークが混ざり，こ の何も入れないときにも見えている自然放射線のピー クは無視できるものです。また，一部に香辛料特有 のピークが出ていますが，これは香辛料に含まれる カリウムです。カリウムの中には自然放射線として カリウム-40という放射性同位元素が含まれているの で，このように自然放射線として観測されるのです。

図 $4 \mathrm{~b}$ が，照射していないコショウと照射してい るコショウを同じレべルで放射能測定し比較したも のです。一見してわかりますが，照射したものに新 たなピークは生じていません。理論上，ほんの少し 出てきそうな放射線であっても, 実際に高感度の測 定を行うと全く検出されません。こうしたことから も，2002 年 4 月に IAEA が出した「食品照射に用い られる放射線による減菌線量レベル $(60 \mathrm{kGy})$ での
照射では，生じる誘導放射能は事実上ゼロである。」 (IAEA-TECDOC1287)という結論が裏付けられます。

（注）IAEA-TECDOC1287（2002 年 4 月） 52 ページの原 文は次の通りです。

The increase in radiation background dose from consumption of food irradiated with gamma rays from cobalt-60 or Cs-137 to an average dose below $60 \mathrm{kGy}$, is insignificant. It is best characterized as zero, as the increase from consumption of 50 $\mathrm{kg} /$ year immediately after irradiation is less than $10-8 \mathrm{mSv} / \mathrm{year}$, or less than $1 / 300,000,000$ of the natural background exposure, which is about 3 $\mathrm{mSv} / \mathrm{year}$.

計算の結果として10のマイナス何十乗とかいう誘 導放射能のレベルは値としては出てきます。そう いう意味ではゼロではないのですけれども，その 検討の中で，いわゆる自然界にある放射線，例え ば食品ですとカリウムー40などがありますが，そう いうものが人体に与える影響を評価しており，そ の健康影響のレベルと比較するとゼロであると言 える，そういう文章になっています。

また, 表 3 はガンマ線測定の検出限界です。緟密 に言いますと, 図4では検出されていなかったので すが, 検出限界值以下のものがあるかもしれないの で検出限界值を示しました。しかし，放射能が検出 されたとしても，この程度のレベルは極めて低い数 值であるので，健康上は問題ないことが一見してわ かります。

表 4 はべータ線の測定結果です。黒コショウと白 コショウで，それぞれ上段が照射したもの，下段が

表 3 ガンマ線測定の検出限界

\begin{tabular}{llcccc}
\hline Nuclide & $\begin{array}{c}\text { Half } \\
\text { life }\end{array}$ & $\begin{array}{c}\gamma \text { energy (MeV) } \\
\text { (\% abundance) }\end{array}$ & $\begin{array}{c}\text { Detection } \\
\text { limit of } \\
\text { count }(\mathrm{n}=3 \sigma)\end{array}$ & $\begin{array}{c}\text { Detection } \\
\text { efficiency } \\
(\%)\end{array}$ & $\begin{array}{c}\text { Detection limit } \\
\text { of radioactivity } \\
(\mathrm{Bq})\end{array}$ \\
\hline${ }^{64} \mathrm{Cu}$ & $12.8 \mathrm{~h}$ & $1.34(0.48)$ & 46 & 0.44 & 34 \\
${ }^{69 \mathrm{~m}} \mathrm{Zn}$ & $13.8 \mathrm{~h}$ & $0.439(100)$ & 101 & 1.6 & $9.4 \times 10^{-2}$ \\
${ }^{111 \mathrm{~m}} \mathrm{Cd}$ & $48.6 \mathrm{~m}$ & $0.246(94)$ & 157 & 3.0 & 1.3 \\
${ }^{113 \mathrm{~m}} \mathrm{Cd}$ & $14 \mathrm{y}$ & $0.265(0.1)$ & 148 & 2.8 & 20 \\
${ }^{115} \mathrm{Cd}$ & $2.21 \mathrm{~d}$ & $0.528(27.5)$ & 84 & 1.2 & $1.5 \times 10^{-1}$ \\
${ }^{115 m} \mathrm{Cd}$ & $43 \mathrm{~d}$ & $0.934(1.9)$ & 64 & 0.88 & 1.5 \\
${ }^{113} \mathrm{Sn}$ & $115.1 \mathrm{~d}$ & $0.392(64.2)$ & 112 & 1.8 & $3.8 \times 10^{-2}$ \\
${ }^{122} \mathrm{Sb}$ & $2.68 \mathrm{~d}$ & $0.564(70)$ & 82 & 1.2 & $5.5 \times 10^{-2}$ \\
${ }^{132} \mathrm{Cs}$ & $6.47 \mathrm{~d}$ & $0.668(97)$ & 75 & 0.96 & $3.7 \times 10^{-2}$ \\
${ }^{135 m} \mathrm{Ba}$ & $28.7 \mathrm{~h}$ & $0.268(15)$ & 154 & 2.8 & $2.9 \times 10^{-1}$ \\
${ }^{199 m} \mathrm{Hg}$ & $44 \mathrm{~m}$ & $0.158(58.4)$ & 167 & 5.2 & 1.4 \\
${ }^{203} \mathrm{Hg}$ & $46.9 \mathrm{~d}$ & $0.279(81.5)$ & 132 & 2.7 & $2.4 \times 10^{-2}$ \\
${ }^{208} \mathrm{~Pb}$ & $0.8 \mathrm{~s}$ & $1.064(90)$ & 58 & 0.56 & 9920 \\
\hline
\end{tabular}


照射していないものですが, 数字的には有意な差は 全くありません。バックグラウンドとして, 何も入 れていないものを測った場合も測定結果は変わら ず，全く問題ないという結果が得られました。

さらに, わざと $(\gamma, \mathrm{n})$ 反応による誘導放射能が 出るといわ机ている銅，亜鉛，カドミニウム，スズ， アンチモン， セシウム , バリウムなどの重金属類の 化合物をコショウの粉の中に添加してみました（図 5，表 5)。18 グラムのコショウに 4.5 グラムずつよ く混ぜて,それに先ほどの $10 \mathrm{MeV}$ の電子線を $100 \mathrm{kGy}$ 照射しました。先ほどと同様に測定し照射直後のガ ンマ線スペクトルを胃ると，予測どおりに， $(\gamma, \mathrm{n})$ 反応の生成物である誘導放射能が出てきました。た
表 4 ベータ線測定結果

\begin{tabular}{lll}
\hline Sample & $\begin{array}{c}10 \mathrm{MeV} \\
\text { electron* }\end{array}$ & $\begin{array}{c}\text { Radioactivity } \\
(\mathrm{cpm}))^{* *}\end{array}$ \\
\hline Black & irradiated & $3.4 \pm 0.5^{* * *}$ \\
pepper & non-irradiated & $2.8 \pm 0.4^{* * *}$ \\
& & \\
White & irradiated & $1.4 \pm 0.3^{* * *}$ \\
pepper & non-irradiated & $1.2 \pm 0.3^{* * *}$ \\
\hline Background & & $1.2 \pm 0.4^{* * *}$ \\
\hline
\end{tabular}

* Irradiated $100 \mathrm{kGy}$.

** Measured immediately after irradiation.

*** All uncertainty statements made refer to $67 \%$ confidence level.

測定限界は $7.0 \times 10^{-2} \mathrm{Bg}$ (酸化ウラン)

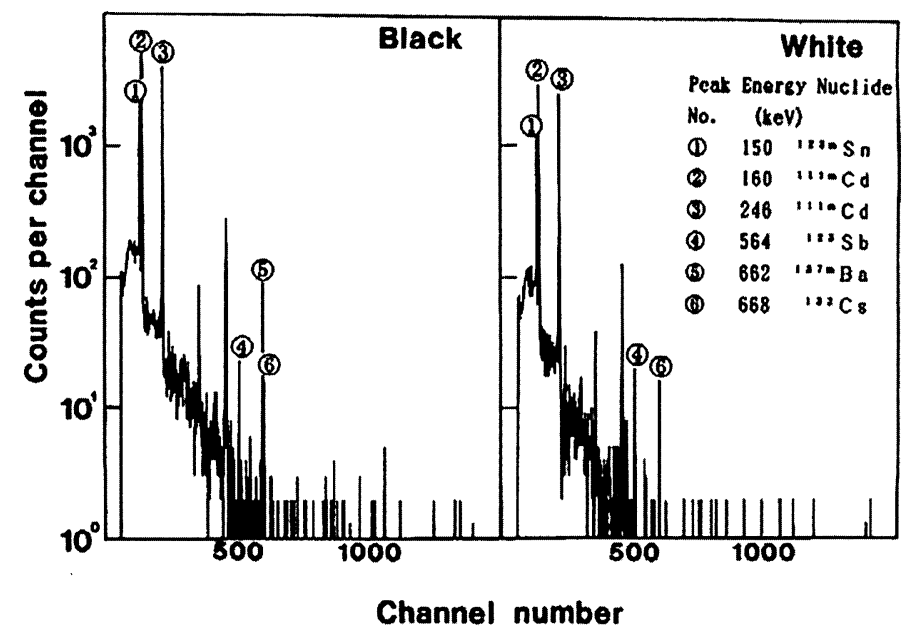

図 5 重金属をわざと加えて照射〜 $100 \mathrm{kGy}$ 照射直後の $\gamma$ 線スペクトル

表 5 重金属をわざと加えて〜検出された放射能の変化

\begin{tabular}{|c|c|c|c|c|}
\hline \multirow{2}{*}{$\begin{array}{l}(\gamma, \mathrm{n}) \\
\text { product }\end{array}$} & \multirow{2}{*}{$\begin{array}{l}\text { Half } \\
\text { life }\end{array}$} & \multirow{2}{*}{$\begin{array}{c}\text { Pepper } \\
\text { Black/White }\end{array}$} & \multicolumn{2}{|c|}{ Radioactivity $(\mathrm{Bq} / \mathrm{g})$ after } \\
\hline & & & 0 days & 5 days \\
\hline \multirow[t]{2}{*}{${ }^{111 \mathrm{~m}} \mathrm{Cd}$} & $48.6 \mathrm{~m}$ & Black & $1.2 \times 10$ & ND \\
\hline & & White & 7.2 & ND \\
\hline \multirow[t]{2}{*}{${ }^{123 m} \mathrm{Sn}$} & $40.08 \mathrm{~m}$ & Black & 9.2 & ND \\
\hline & & White & 5.7 & ND \\
\hline \multirow[t]{2}{*}{${ }^{122} \mathrm{Sb}$} & $2.68 \mathrm{~d}$ & Black & $2.0 \times 10^{-1}$ & $6.5 \times 10^{-2}$ \\
\hline & & White & $2.1 \times 10^{-1}$ & $6.5 \times 10^{-2}$ \\
\hline \multirow[t]{2}{*}{${ }^{137 \mathrm{~m}} \mathrm{Ba}$} & $2.552 \mathrm{~m}$ & Black & 2.2 & ND \\
\hline & & White & ND & ND \\
\hline \multirow[t]{2}{*}{${ }^{132} \mathrm{Cs}$} & $6.47 \mathrm{~d}$ & Black & $1.6 \times 10^{-1}$ & $8.8 \times 10^{-2}$ \\
\hline & & White & $1.2 \times 10^{-1}$ & $7.7 \times 10^{-2}$ \\
\hline
\end{tabular}

ND] Not detected. 
だ，非常に小さいレべルであり，これはすぐに消え てしまう放射性核種なので，例えば 5 日後に測った 場合には，ほとんどの誘導放射能はもう検出されな いレベルに落ちています。

このように安全性は確認できましたが，さらに， 1 グラムというかなり大量の照射直後の黒コショウ を私達が食べ続けたと仮定して, 預託線量当量を ICRPの Publication30に出ている表により計算しま した。この計算方法ですが，重金属を添加した試料 に扔いて検出された放射能と, 通常の照射コショウ の誘導放射能と放射線影響の推定ということで, 加 えた重金属量と, ナチュラルな黒コショウに含まれ ていた重金属量との比率を計算し, わざと重金属類 を加えた場合に測定された放射能レベルから，ナ チュラルな場合の放射能レベルはどの程度かを比率 から計算します。その結果，出てきた值が，表 6 の 值ですが，もう検出器では到底検出できない位の $10^{-5} \mathrm{~Bq} / \mathrm{g}$ や $10^{-6} \mathrm{~Bq} / \mathrm{g}$ といった大変小さな值です。 この值を ICRP の Publication30に出ている表に当て はめると預託線量当量が出てきます。ST Wall とい う表記は胃壁のことで，胃袋の中に入ったときにど の位の被ばく量があるかということですが，これも
$10^{-16} \mathrm{~Sv} / \mathrm{g}$ と非常に少量です。もともとコショウに天 然に含まれているカリウム-40, これはカリウムが 含まれている食品の中にはどれにでも含まれてい て，もちろん私達の体内に含まれている自然放射能 ですが, これによって受ける被ばく線量と比較して も，100万分の 1 以下くらいにしかならないというこ とで, 確かに問題ないということが確認できました。

\section{まとめ}

文献を調べて理論計算による評価をしても，コバ ルト-60 あるいはセシウム-137 から出てくるガンマ 線, $5 \mathrm{MeV}$ の X 線, $10 \mathrm{MeV}$ までの電子線といった放 射線を当てることについては, 照射食品の誘導放射 能に関して問題ないことが理解できました。また， 実際に照射香辛料に対する放射能測定を行っても， 誘導放射能およびその影響は無視できるレベルであ ること,むしろ, コバルト-60 あるいはセシウム -137 から出てくるガンマ線, $5 \mathrm{MeV}$ の X 線, $10 \mathrm{MeV}$ まで の電子線といった通常, 食品の照射に用いるレベル の放射線では, 自然放射能よりも低いレベルの反応 しか起こらないということが確認できました。

(2006 年 2 月 17 日受理)

表 6 Estimation of induced radioactivity in $100 \mathrm{kGy}$-irradiated pepper and caluculation of commited dose equivalent $\left(\mathrm{H}_{50}\right)$ in gastrointestinal tract per intake of $1 \mathrm{~g}$ of irradiated pepper just after irradiation

\begin{tabular}{|c|c|c|c|c|c|}
\hline \multirow{2}{*}{ Nuclide } & \multirow{2}{*}{$\begin{array}{l}\text { Half } \\
\text { life }\end{array}$} & \multirow{2}{*}{$\begin{array}{c}\text { Pepper } \\
\text { Black/White }\end{array}$} & \multicolumn{2}{|c|}{ Radioactivity $(\mathrm{Bq} / \mathrm{g})$} & \multirow{2}{*}{$\mathrm{H}_{50}(\mathrm{~Sv} / \mathrm{g})$} \\
\hline & & & metal-added & natural & \\
\hline \multirow[t]{2}{*}{${ }^{111 \mathrm{~m}} \mathrm{Cd}$} & $48.6 \mathrm{~m}$ & Black & $1.2 \times 10$ & $3.5 \times 10^{-5}$ & $4.0 \times 10^{-16}$ \\
\hline & & White & 7.2 & $1.1 \times 10^{-5}$ & $\begin{array}{l}1.3 \times 10^{-16} \\
\text { (ST wall) }\end{array}$ \\
\hline \multirow[t]{2}{*}{${ }^{123 \mathrm{~m}} \mathrm{Sn}$} & $40.08 \mathrm{~m}$ & Black & 9.2 & $3.9 \times 10^{-4}$ & $3.0 \times 10^{-16}$ \\
\hline & & White & 5.7 & $8.0 \times 10^{-5}$ & $\begin{array}{l}6.1 \times 10^{-17} \\
\text { (ST wall) }\end{array}$ \\
\hline \multirow[t]{2}{*}{${ }^{122} \mathrm{Sb}$} & $2.68 \mathrm{~d}$ & Black & $2.0 \times 10^{-1}$ & $1.9 \times 10^{-8}$ & $3.8 \times 10^{-16}$ \\
\hline & & White & $2.1 \times 10^{-1}$ & $3.6 \times 10^{-8}$ & $\begin{array}{l}7.2 \times 10^{-16} \\
\text { (LLI wall) }\end{array}$ \\
\hline \multirow[t]{2}{*}{${ }^{137 m} \mathrm{Ba}$} & $2.552 \mathrm{~m}$ & Black & 2.2 & $8.7 \times 10^{-4}$ & $2.6 \times 10^{-15}$ \\
\hline & & White & - - & -- & (ST wall) \\
\hline \multirow[t]{2}{*}{${ }^{132} \mathrm{Cs}$} & $6.47 \mathrm{~d}$ & Black & $1.6 \times 10^{-1}$ & $1.7 \times 10^{-8}$ & $1.0 \times 10^{-17}$ \\
\hline & & White & $1.2 \times 10^{-1}$ & $1.7 \times 10^{-9}$ & $\begin{array}{l}1.0 \times 10^{-18} \\
\text { (ST wall) }\end{array}$ \\
\hline${ }^{40} \mathrm{~K}$ & $1.26 \times 10^{9} \mathrm{y}$ & Black & & 3.7 & $2.0 \times 10^{-8}$ \\
\hline \multicolumn{2}{|c|}{ (Natural activity in the sample) } & e) White & & $1.8 \times 10^{-1}$ & $\begin{array}{l}9.9 \times 10^{-10} \\
\text { (ST wall) }\end{array}$ \\
\hline
\end{tabular}

ST wall: Stomach wall. LLI wall: Lower large intestine wall 